\title{
Do fiscal rules reduce government borrowing costs in developing countries?
}

Thornton, John; Vasilakis, Chrysovalantis

\section{International Journal of Finance and Economics}

DOI:

10.1002/ijfe. 1771

Published: 13/10/2020

Peer reviewed version

Cyswllt i'r cyhoeddiad / Link to publication

Dyfyniad o'r fersiwn a gyhoeddwyd / Citation for published version (APA):

Thornton, J., \& Vasilakis, C. (2020). Do fiscal rules reduce government borrowing costs in developing countries? International Journal of Finance and Economics, 25(4), 499-510. https://doi.org/10.1002/ijfe.1771

\footnotetext{
Hawliau Cyffredinol / General rights

Copyright and moral rights for the publications made accessible in the public portal are retained by the authors and/or other copyright owners and it is a condition of accessing publications that users recognise and abide by the legal requirements associated with these rights.

- Users may download and print one copy of any publication from the public portal for the purpose of private study or research.

- You may not further distribute the material or use it for any profit-making activity or commercial gain

- You may freely distribute the URL identifying the publication in the public portal ?
}

Take down policy

If you believe that this document breaches copyright please contact us providing details, and we will remove access to the work immediately and investigate your claim. 


\title{
Do fiscal rules reduce government borrowing costs in developing countries?
}

\author{
By
}

\author{
John Thornton \\ Office of Technical Assistance, United States Department of the Treasury, USA; and The Business \\ School, Bangor University, UK. Email: John.Thornton@otatreas.us \\ and \\ Chrysovalantis Vasilakis \\ The Business School, Bangor University, UK; and Institut de Recherches Economiques et Social, \\ Université Catholique de Louvain, Belgium. E-mail c.vasilakis@bangor.ac.uk
}

\begin{abstract}
We examine whether adopting numerical fiscal rules framework to guide fiscal policy helped reduce the cost of borrowing by governments in a sample of 61 low- and middle-income countries for 1985-2017, 24 of which adopted such rules. We address the self-selection problem of policy adoption by applying a variety of propensity score matching methods and show that the average treatment effect of fiscal rules on government borrowing costs is quantitatively quite large and statistically significant in rule adopting countries. We also find that the presence of institutional arrangements to strengthen fiscal rules results in a larger reduction in borrowing costs than is the case without these arrangements, which is consistent with strong rules adding to the credibility of the fiscal policy framework.
\end{abstract}

Keywords: Fiscal rules, government borrowing costs, propensity score matching

JEL: E43, G12, H60 


\section{Do fiscal rules reduce government borrowing costs in developing countries?}

\section{INTRODUCTION}

Although numerical fiscal rules have been a popular addition to fiscal frameworks since the early 1990s, their effectiveness in lowering government borrowing costs remains controversial. ${ }^{1}$ A theoretical basis for adopting fiscal rules to reduce borrowing costs is provided by Hatchondo and Martinez (2009) who present a model in which governments issuing bonds with a duration like the average for emerging market countries face an interest rate that is substantially higher and more volatile compared to when only short- term debt is issued. Hatchondo, Martinez, and Padilla (2011) demonstrate the importance of debt dilution in accounting for the level and volatility of the interest rate spread paid by sovereigns; and Hatchondo, Martinez, and Roch (2015) show how introducing a fiscal rule lowers sovereign risk and generates welfare gains because the rule limits debt dilution. ${ }^{2}$ With the fiscal rule, lenders expect lower future government debt levels, which accounts for the decline in interest rates at which the government can borrow. Thus, for a given level of indebtedness, the government is able to borrow paying at a lower interest rate.

The empirical evidence on the impact of fiscal rules on borrowing costs is mixed and relates mainly to the experience of US states and some European economies. For the US, this evidence includes: Eichengreen and Bayoumi (1994) and Bayoumi, Goldstein, and Woglom (1995), who report that constitutional restraints to borrowing reduce the costs of borrowing by US states; Poterba and Rueben (1999ab), who find that rules on US states' expenditure, deficits, and debt reduce their borrowing costs except when a state also imposes limitations on the ability to raise taxes; Poterba and Rueben (2001), who find that a sudden increase in the fiscal deficit raises state financing costs, but that the rise is smaller if the state has a strict fiscal rule; and Johnson and Kriz (2005), who find that numerical fiscal rules reduce borrowing costs but that the effect operates indirectly by improving credit ratings. For European countries, the

\footnotetext{
${ }^{1}$ For example, the IMF’s Fiscal Rules Dataset, 2016 lists 93 countries as having adopted national and supranational numerical fiscal rules to help guide fiscal policy.

2 Debt dilution refers to the reduction in the value of existing debt triggered by the issuance of new long-term debt since rational investors anticipate that additional borrowing by future governments will increase the risk of default on long-term bonds issued by the current government and, thus, offer a lower price for these bonds.
} 
evidence includes Iara and Wolf (2014), who report that numerical rules only impact on borrowing costs of euro area countries at times of market stress; Heinemann, Osterloh, and Kalb (2014), who find that the impact of numerical rules on euro area countries is less important once historical fiscal preferences are considered; and Feld, Kalb, Moessinger, and Osterloh (2012), who find a robust negative effect of fiscal rules on bond spreads for Swiss cantons.

However, fiscal rules are not just a policy for developed countries. The governments of developing countries typically face high borrowing costs partly because they suffer from poor policy credibility. ${ }^{3}$ In recent years, 24 low- and middle-income developing countries have adopted numerical fiscal rules with the specific objective of building policy credibility that would lead, among other things, to a reduction in borrowing costs (Schaechter, Kinda, Budina, and Weber, 2012; IMF, 2009). Given the considerable executive and legislative effort involved in the adoption of rules and the relative scarcity of human capital in developing economies, whether or not their adoption has impacted on their borrowing costs is an important question. Accordingly, in this paper we examine the impact of the adoption of fiscal rules on the borrowing costs of governments in developing countries. The majority of low- and middle income developing countries obtain their fiscal financing primarily from domestic credit markets (mainly banks) and official international financial institutions. As financing from the latter source is typically at below market interest rates, we focus on domestic borrowing costs for which we have two indicators. The first is the spread between the interest rate charged by domestic banks on loans to private sector entities in developing countries and the interest rate at which the governments of these countries can borrow through the issuance of short-term securities. In this market, the cost of borrowing by the government is typically lower than it is for private sector entities. Accordingly, if adopting fiscal rules reduces the risk premium on government borrowing, we would expect this spread to widen as the cost of borrowing by the government declines relative to that of private sector entities. Second, as it is conceivable that the spread might widen because of factors impacting only on private borrowing costs, we also examine developments in the absolute cost of borrowing by developing country governments by examining the impact of fiscal rule adoption on the interest rate on short-term government securities (treasury bills).

\footnotetext{
${ }^{3}$ We define developing countries as the low-income and lower middle income countries in the World Bank's country classification scheme; in 2017 (the final year of our sample) these countries had a GNI per capita of $\$ 3,895$ or less.
} 
One issue with the approach taken in many of the empirical studies discussed above is that they typically search for rule effects by incorporating a fiscal rule adoption dummy into a data panel and examining the statistical significance and sign of the coefficient on the dummy. A problem with this approach is that it ignores the self-selection problem of policy that arises when a country's policy choice is non-random. In particular, systematic correlation between the policy choice and other covariates will cause the selection on observables problem, which can lead to biased estimates. To address this issue, we adopt a more appropriate methodology, which is to evaluate the treatment effect of numerical fiscal rules on borrowing costs. To control for the self-selection problem of policy adoption, we make use of a variety of propensity score matching methods that have been developed in the treatment effect literature and have been applied to macroeconomic issues, for example, by Lin and Ye (2007, 2009, 2010, 2013), Glick, Guo, and Hutchinson (2006), Persson (2001), and Thornton and Vasilakis (2016). Our results should offer encouragement to those countries that have adopted or are considering adopting such rules: we find the average treatment effect of fiscal rules on government borrowing costs to be strong and robust. On average, in our baseline case, the adoption of a numerical fiscal rule has been associated with a reduction in the relative costs of borrowing by the government of between 1.2-1.8 percentage points of the borrowing spread in domestic credit markets and between 1.1-1.7 percentage points in treasury bill rates. We also subject our baseline results to several robustness tests and find that the impact of fiscal rules on government borrowing costs can be affected by factors such as whether a country receives debt reduction, whether it conducts policies that repress the financial system, whether it has a weak banking system, and whether there are institutional arrangements in place to increase the likelihood of policymakers adhering to the rules.

The rest of the paper is organized as follows. Section 2 describes our dataset and methodology. In Section 3, we estimate the average treatment effect of fiscal rules on the treated employing a variety of propensity score matching methods, and present results from subjecting our baseline result to a series of robustness tests. Section 4 provides some additional results that shift the focus to developments in treasury bill interest rates and to the impact of the strength of fiscal rules on borrowing costs. Section 5 concludes. 


\section{DATA AND METHODOLOGY}

Our panel dataset consists of 61 developing countries for the years 1985-2017, of which 24 adopted numerical fiscal rules in recent years. Most of the data are drawn from the World Bank's World Development Indicator Database and the IMF's World Economic Outlook database. ${ }^{4}$

\subsection{The treatment group and the control group}

The treatment group includes 24 developing countries that adopted fiscal rules by the end of 2017 . The most common fiscal rules adopted apply to the fiscal deficit and the level of public debt, which are the focus of our study. ${ }^{5}$ We obtain the starting years for fiscal rule adoption in country from Schaechter et al. (2012) updated in the IMF Fiscal Rules Dataset, $2016 .{ }^{6}$ Panel A of Table 1 lists the 24 fiscal rule adopting countries and the year in which the rule was adopted, and panel B of the table lists the 37 nonrule adopting developing countries. To ensure that the treatment group and the control group are reasonably comparable, our control group only includes non-fiscal rule countries that have a real GDP per capita at least as large as that of the poorest rule adopting country. Summary statistics for all the variables are present in Table 2 and variable definitions and data sources are provided in the Appendix. There are no obvious major differences in the descriptive statistics between the two groups of countries. Focusing on the sample median outcomes, borrowing spreads were somewhat higher in the treatment group, though not by much; treasury bill rates, levels of public sector indebtedness, and GDP growth were broadly similar for both groups, and both groups had reasonably low inflation rates (below 10\%), were relatively open to foreign trade, maintained exchange rate regimes that were relatively fixed, and included countries that had experienced bouts of hyperinflation. The main differences are that the

\footnotetext{
${ }^{4}$ We have also drawn on data from Abbas, Belhocine, El Ganainy, and Horton ((2010) on public debt, Reinhart and Rogoff (2004) (and their subsequent updates) for the exchange rate regime classification, and on the CIA Factbook for information on whether countries have federal or unitary fiscal systems.

${ }^{5}$ In practice, countries adopting fiscal rules have typically opted for rules that are linked closely to debt sustainability, with the most common rules specifying some measure of budget balance (overall balance, structural or cyclically adjusted balance, or balance 'over the business cycle'), and an explicit limit on, or target for, public debt. A few countries have also adopted rules relating to a minimum level of government revenue (see Schaechter et al., 2012) for a listing of the different types of rules adopted.

${ }^{6}$ The dataset is available at: https://www.imf.org/external/datamapper/fiscalrules/map/map.htm.
} 
control group countries were substantially wealthier (as measured by GDP per capital) and experienced greater volatility in all their economic variables.

\subsection{Propensity score matching methods}

An important econometric issue in evaluating the treatment effects of fiscal rules is the non-random selection of policy adoption., which arises when a country's fiscal rule choice is systematically correlated with a set of observable variables that also affect the outcomes. To address the self-selection problem, we make use of different propensity score matching methods that have been developed in the treatment effect literature and have been applied to a number of macroeconomic issues, for example, by Lin and Ye (2007, 2009, 2010, 2013), Glick, Guo, and Hutchinson (2006), Persson (2001), and Thornton and Vasilakis (2017). In particular, we employ four commonly used propensity score matching methods. The first is the nearest-neighbour matching with replacement, which matches each treated country to $n$ control countries that have the closest propensity scores. We use two nearest-neighbour matching estimators: $n=1$ and $n=3$. The second method is radius matching, which performs the matching based on estimated propensity scores falling within a certain radius. We employ a wide radius $(r=0.05)$, a medium radius $r=0.03$ ), and a tight radius $r=0.01$ ). The third method is the kernel matching method, which matches a treated group country to all control group countries weighted in proportion to the closeness between the treated group country and the control group country. The final method is the regression adjusted local linear matching method. $^{7}$

\section{ESTIMATING THE AVERAGE TREATMENT EFFECTS}

This section estimates the average treatment effects of fiscal rule adoption on the two measures of the cost of government borrowing: the domestic interest rate spread, which is the average interest rate on bank lending to the private sector minus the treasury bill rate; and the treasury bill rate itself. As discussed above, if fiscal rule adoption adds credibility to government policy, we would expect the interest rate the government pays to borrow to decline leading, ceteris paribus, to a widening of the lending spread in the domestic market (as treasury bill rates decline relative to the interest rate charged

\footnotetext{
${ }^{7}$ The propensity score matching techniques are discussed in detail in Lin and Ye (2007).
} 
by banks to private entities) and a fall in treasury bill rates relative to countries that did not adopt a fiscal rule.

\subsection{Estimating the propensity scores}

The first step is to test for factors that increase the probability that a fiscal rule will be adopted. To this end, we employ a panel binary response model to test for factors that increase the probability that a fiscal rule will be adopted. ${ }^{8}$ In the model, the dependent variable is a dummy variable that takes the value 1 if a country $i$ adopted a numerical fiscal rule in year $t$, and 0 otherwise. We choose independent variables on the basis of recent work that throws light on key factors behind a country's decision to adopt a fiscal rule as summarized in Altunbas and Thornton (2017). In this literature, for example, Debrun and Kumar (2007) and Roubini and Sachs (1989) cite large and persistent fiscal deficits and growing public debt as a justification for the introduction of fiscal rules; the IMF (2009) reports evidence that fiscal rules tend to be introduced in countries that have already made progress in achieving fiscal and economic stability; Prud'homme (1995) and Webb (2004) attest to important differences in the conduct and outcome of fiscal policy between federal and unitary countries; and Giavazzi and Pagano (1988) and Frenkel et al. (1991) discuss the impact of government deficits and public debt levels on the relative success of different exchange rate regimes. Thus, this literature suggests that the probability of a country adopting a fiscal rule is greater if it has a high level of public debt, if economic conditions are relatively stable, if it is relatively open to international trade and its exchange rate regime is relatively inflexible, and if it is decentralized fiscally. Accordingly, we include in our baseline probit estimation: the ratio of public debt to GDP; the rate of inflation, the rate of real GDP growth, real GDP per capita; the relative flexibility of the exchange rate regime (the Reinhart and Rogoff coarse grid categorization, which ranges from 1 (least flexible) to 5 (most flexible)); openness to international trade (exports plus imports as a per cent of GDP); and a 0-1 dummy variable to indicate whether a country is a federation.

The baseline probit results are reported in the column 1 of Table 3. Broadly, the probability of a developing country adopting a numerical fiscal rule is greater if the stock of debt and inflation are relatively low, if GDP per capita is relatively high, if the economy is relatively closed to foreign trade, if

\footnotetext{
${ }^{8}$ See Baltagi (2008) for a discussion of the probit methodology.
} 
the exchange rate regime is relatively inflexible, and if the country is a federation; the growth of real GDP is not statistically significant. We carry out several robustness checks on our baseline result. ${ }^{9}$ First, we take account of the fact that many countries in our sample received debt reduction over the period either because of multilateral debt relief initiatives or as the outcome of bilateral negotiations with official and private creditors. For some countries, the debt reduction was very large-for example, accumulating in current US dollars to the equivalent of over $100 \%$ of 2017 GDP. ${ }^{10}$ Failing to take account of debt reduction would likely bias our results. Probit results including debt reduction are reported in column 2 of Table 3. The coefficient on debt reduction is statistically significant (albeit at the $10 \%$ level) and positive, indicating that countries that experienced debt relief are more likely to adopt a fiscal rule.

Second, in many developing countries government access to domestic market financing is facilitated by financial repression, for example, through capital account restrictions and exchange controls that orchestrate a "forced home bias" in the portfolio of financial institutions, "prudential" regulatory measures requiring that institutions hold government debt in their portfolios, interest rate ceilings, and direct ownership or extensive management of banks and other financial institutions. In particular, financial repression can lead to a reduction of domestic debt when the real rate of interest on government bonds is negative or below the real market rate. What is the likely impact of financial repression on fiscal rule adoption? On the one hand, it might mitigate against adoption as the repression reduces the burden of debt management on fiscal policy. On the other hand, financial repression might make adopting a fiscal rule more attractive since the rule would likely be easier to meet. It might also mean that external public debt rather than total public debt may be the main driver of any decision to adopt a fiscal rule. We try to control for each of these two possibilities. First, we capture the impact of financial repression by adding to the baseline estimate a dummy variable that takes the value of 1 if the interest rate on domestic treasury bills is negative and 0 otherwise. This dummy seeks to capture the impact of the so-called "liquidation effect" of financial repression on domestic debt discussed by Reinhart and Sbrancia (2015). The relevant probit estimation is reported in column 3 of Table 3 . The coefficient on the financial repression dummy is positive and statistically significant suggesting that countries that can "liquidate"

\footnotetext{
${ }^{9}$ We are grateful to an anonymous referee of the journal for suggesting some of these robustness tests.

${ }^{10}$ Of the countries in our sample, Ethiopia, Guyana, Liberia, Madagascar, Mozambique, Nicaragua, Sierra Leone, São Tomé and Principe, and Zambia received debt reduction to the equivalent of over 100\% of 2017 GDP during 1985-2017.
} 
domestic debt through financial repression are more likely to adopt a fiscal rule. Second, we capture the potentially greater importance of external debt as a driver of fiscal rule adoption by including external public debt in place of total public debt in the probit estimates of the likelihood of fiscal rule adoption on the basis that governments have little direct control over external creditors. The probit results for this estimate are reported in column 4 of Table 3 . The coefficient on external debt is statistically significant and much larger that on total public debt (column 1) and the negative sign on the coefficient is consistent with countries preferring to bring external debt to a more manageable level prior to adoption of a fiscal rule.

For our third robustness test, we try to take account of the possibility that the widening of borrowing spreads associated with the adoption of a fiscal rule reflected developments in the cost of borrowing by the private sector rather than in the borrowing costs of the government-i.e., the widening spread might reflect an increase in the interest rates charged by banks to domestic private sector borrowers rather than a reduction in government borrowing costs. For example, if the banks in fiscal rule adopting countries for some reason are weaker (e.g., because of larger loan losses) than in non-rule adopting countries, their bank loan rates might be higher, and this may account for the wider spread. We try to account for this possibility by adding to the baseline probit a crude measure of the relative strength of national banking systems. Because of the paucity of time series indicators of bank strength in the developing countries in our sample, we include a 0-1 dummy variable with 1 indicating a year of banking crisis and 0 indicating no crisis. ${ }^{11}$ Our assumption is that it is weaker banking systems that experience crises and where banks might charge higher lending rates in an attempt to offset loan losses. ${ }^{12}$ The probit results including the banking crisis dummy are reported in column 4 of Table 3 . The coefficient on the banking crisis variable is negative and statistically significant suggesting that countries with weak banks are less likely to adopt a rule.

\subsection{Results from matching}

\footnotetext{
${ }^{11}$ We draw on Laeven and Valencia (2012) for data on systemic banking crises.

${ }^{12}$ There is some evidence that bank credit spreads spike during financial crisis (Akinci and Queralto, 2016) and increase lending rates in post crisis periods( Chava and Amiyatosh Purnanandam ,2010).
} 
The matching results for the borrowing spreads are presented in Table 4. The baseline result for the estimated average treatment effect on the treated (ATTs) is reported in the first row of the table; the estimated ATTs are positive, highly statistically significant, and quite large in magnitude. On average, a numerical fiscal rule widens the borrowing spread by between 1.8 to 2.6 percentage points. That is, the domestic borrowing spread widens following the adoption of a numerical fiscal rule, which we interpret as reflecting a fall in the cost of borrowing by the government in the domestic credit market. The matching results associated with debt reduction are reported in row 2 of the table where the estimated ATTs remain positive, statistically significant, and of a similar magnitude to the baseline result. As such, the adoption of fiscal rules has a significant impact in widening the borrowing spread in developing countries even after controlling for debt reduction, which we again interpret as reflecting a relative decline in the cost of government borrowing. In row 3, we present the matching results for financial repression where the estimated ATTs remain positive and are statistically significant in all but one case (though sometimes only at the $10 \%$ level). Thus, relative borrowing costs for the government decline with the adoption of a fiscal rule even when the government has a near-captive domestic credit market. The matching results associated with external public debt (in place of total public debt) as a driver of fiscal rule adoption are reported in row 4. The estimated ATTs are again positive and statistically significant; in addition, the impact on the borrowing spread is larger than that for total debt (rows 1-3), with the borrowing spread widening between 2.2 to 3.5 percentage points. Thus, countries that can reduce their external debt are both more likely to adopt a fiscal rule and likely to benefit from a larger improvement in borrowing costs. The final set of ATTs reported in row 5 of the table are associated with the presence of weak banking systems, where the ATTs are again positive and statistically significant.

\section{ADDITIONAL RESULTS}

In this section, we present results from two additional perspectives of the impact of fiscal rule adoption on government borrowing costs. In the first, we shift the focus from borrowing spreads to looking directly at developments in the interest rate that the government has to pay to borrow-i.e., we examine developments in the interest rate on treasury bills in developing countries that adopted a rule relative that in countries that did not. Second, we take account of the fact that the likelihood that of fiscal rules 
impacting on the credibility of fiscal policy-and hence on government borrowing costs-will depend in part on the credibility of the rule itself. In turn, this will depend on the likelihood that the rule will be adhering to. Fiscal rules are likely to be more credible if they are strengthened by an institutional framework that increases the likelihood of policymakers adhering to them. In this regard, one would expect fiscal rules with supportive institutional arrangements ("strong" rules) to be more credible than rules that do not have such arrangements ("weak" rules).

\subsection{Developments in treasury bill rates}

To ensure that we are capturing developments in government borrowing costs, we apply propensity score matching methods to evaluate the treatment effect of numerical fiscal rules on treasury bill yields in countries that have adopted such a rule. In this case, if there are positive effects on the credibility of the fiscal framework from adopting fiscal rules, we would expect the ATTs to be negative. We employ the probit results reported in Table 3 to evaluate the treatment effect for both nominal and real (i.e., inflation adjusted) treasury bill rates. These results are reported in Table 5 where panel A reports the matching results for nominal rates and panel B reports the results for real rates. In both sets of results and for each of the robustness tests applied in the case of borrowing spreads, the ATTs are consistently negative and in most cases they are statistically significant. In the baseline cases for example, the adoption of a fiscal rule is associated with a decline in nominal treasury bill rates of between 1.1 to 1.7 percentage points and a decline in real treasury bill of 0.7 to 1.9 percentage points. Thus, numerical fiscal rules have quantitatively statistically significant and quite large effects on lowering interest rates on treasury bills.

\subsection{The strength of fiscal rules}

To distinguish between those countries that adopted a "strong" fiscal rule and those that adopted a "weak" fiscal rule we calculate an "index" of fiscal rule strength. The index is a simple aggregation of the number of supportive arrangements put in place from the list of desirable supporting arrangements set 
out in Schaechter et al. (2012). ${ }^{13}$ We then attribute a strong fiscal rule to a country if the index score for the country is above the median score for all countries in the sample that adopted a rule. Next, we create a 0-1 dummy where 1 indicates a country with a relatively strong fiscal rule (i.e., an index score above the median) and 0 otherwise. In Table 6 , we report probit results for the likelihood that a country will adopt a strong fiscal rule employing the same independent variables that we used previously for the likelihood of fiscal rule adoption. As can be seen, in general the same variables that influence rule adoption also influence the likelihood that a strong rule will be adopted. The exception is with respect to GDP per capita, where higher-income developing countries appear less likely to adopt a strong rule. The associated matching results for borrowing spreads are reported in Table 7. They indicate that the adoption of a strong fiscal rule is associated with a widening of the borrowing spread, which we interpret as consistent with a fall in the cost of borrowing by the government relative to the private sector. In the baseline case, for example, the borrowing spread widens by between 3.6 to 6.5 percentage points, which is much greater than the increase in the borrowing spread associated fiscal rule adoption more generally (as reported in Table 4).

\section{CONCLUSIONS}

Previous work on the impact of fiscal rules on government borrowing costs has produced mixed results and has mainly examined the experience of developed economies. In this study, we evaluate the treatment effect of fiscal rules in 24 developing countries that had adopted fiscal rules by the end of 2017 . Using a variety of propensity score matching methods, we show that the average treatment effect of fiscal rules on government borrowing costs is quantitatively quite large and statistically significant. This result holds when we examine the spread between the interest rate charged by domestic banks on loans to private sector entities and the interest rate at which the governments of these countries can borrow through the issuance of short-term securities. In this case, the adoption of a fiscal rule is associated with a widening of the spread, which we interpret as reflecting a fall in government borrowing costs relative to countries that did not adopt a rule. It also holds when we examine the impact of fiscal rule adoption on the interest rate

\footnotetext{
13 The list comprises the following variables: (i) enforcement score; (ii) coverage score; (ii) legal basis score; (iii) supranational rules score; (iv) index of supporting procedures for monitoring of compliance and enforcement; (v) flexibility score; (vi) average number of fiscal rules; and (vii) the ratio of national to total fiscal rules in each country.
} 
governments pay on treasury bills, where rates fall relative to those in countries that have not adopted a fiscal rule. These results are robust to controlling debt reduction, financial repression, and the relative strength of banking systems. Finally, we also find that the presence of institutional arrangements to strengthen fiscal rules to increase the likelihood that they will be adhered to, result in a larger reduction in borrowing costs than in the baseline case. This is consistent with strong rules adding greater credibility of the fiscal policy framework. Our results should be of interest to governments of developing countries that have already adopted or are considering adopting fiscal rules in the hope of, among other objectives, reducing their borrowing costs.

\section{REFERENCES}

Abbas, S.A., Belhocine, N., El Ganainy, A., \& Horton, M. (2010). A historical public debt database. IMF Working Paper No. 10/245.

Akinci, O., \& Queralto, A. (2016). Credit spreads, financial crises, macroprudential policy. FRBNY Staff Report No. 802.

Altunbaş, Y., \& J. Thornton, J. (2017). Why do countries adopt fiscal rules? The Manchester School, 85, 65-87.

Baltagi, B.H. (2008). Econometric analysis of panel data $\left(4^{\text {th }}\right.$ Ed.). Chester: Wiley.

Bayoumi, T., Goldstein, M., \& Woglom, G. (1995). Do credit markets discipline sovereign borrowers? Evidence from the United States. Journal of Money, Credit and Banking, 27, 1046-1059.

Chava, S., \& Purnanandam, A. (2010). Is default risk negatively related to stock returns? The Review of Financial Studies, 23, 2523-2559,

Debrun, X., \& Kumar, M.S. (2007). The discipline enhancing role offiscal institutions. IMF Working Paper No. 07/171.

Eichengreen, B., \& Bayoumi, T. (1994). The political economy of fiscal restrictions: implications for Europe from the United States. European Economic Review, 38, 783-791. 
Feld, L.P., Kalb, A., Moessinger, M.D., \& Osterlich, S. (2013). Sovereign bond market reactions to fiscal rules-the Swiss experience. CESifo Working Paper No. 1495.

Frenkel, J.A., Goldstein, M., \& Masson, P.R. (1991). Characteristics of a successful exchange rate system. IMF Occassional Paper No. 82.

Giavazzi, F., \& Pagano, M. (1988).The advantage of tying one’s hands: EMS discipline and central bank credibility. European Economic Review, 32, 1055-1075.

Glick, R., Guo, X., \&. Hutchinson, M. (2006). Currency crises, capital account liberalization, and selection bias. Review of Economics and Statistics, 88, 698-714.

Hatchondo, J.C., Roch, F., \& Martinez, L. (2015). Fiscal rules and the sovereign default premium. IMF Working Paper No. 12/13.

Hatchondo, J.C., Martinez, L., \& Padilla, C.S. (2011). Debt dilution and sovereign default risk. Journal of Political Economy, 124, 383-1422.

Hatchondo, J. C., \& Martinez, L. (2009). Long-duration bonds and sovereign defaults. Journal of International Economics, 79, 117-125.

Heinemann, F., Osterloh, S., \& Kalb, A. (2014). Sovereign risk premia: the link between fiscal rules and stability culture. Journal of International Money and Finance, 41, 110-127.

Iara, A., \& Wolff, G.B. (2014). Rules and risk in the Euro area. European Journal of Political Economy, $34,222-236$.

IMF. (2009). Fiscal rules-anchoring expectations for sustainable public finances. IMF Staff Paper, December 16.

Johnson, C. L., \& Kriz, K.A. (2005). Fiscal institutions, credit ratings, and borrowing costs. Public Budgeting and Finance, 25, 84-103.

Laeven, L., \& Valencia, F. (2012). Systemic Banking Crises Database : An Update. IMF Working Paper No. $12 / 163$.

Lin, S., \& Ye, H. (2013). Does inflation targeting help reduce dollarization? Journal of Money, Credit and Banking, 45, 1253-1274.

Lin, S., \& Ye, H. (2010). Dollarization does promote trade. Journal of International Money and Finance, 29, 1124-1130.

Lin, S., \& Ye, H. (2009). Does inflation targeting make a difference in developing countries? Journal of 
Development Economics, 89, 118-123.

Lin, S., \& Ye, H. (2007). Does inflation targeting really make a difference? Evaluating the treatment effect of inflation targeting in seven industrial countries. Journal of Monetary Economics, 54 , 2521-2533.

Mauro, P., Romeu, R., Blinder, A., \& Zaman, A.(2015). A modern history of fiscal prudence and profligacy. Journal of Monetary Economics, 15, 55-70.

Perrson, T. (2001).Currency union and trade: how large is the treatment effect? Economic Policy, 16, 433-448.

Poterba, J. M., \& Rueben, K.S. (2001). Fiscal news, state budget rules, and tax exempt bond yields. Journal of Urban Economics, 50, 537-562.

Poterba, J.M., \& Rueben, K.S. (1999a). Fiscal rules and state borrowing costs: evidence from California and other states. Public Policy Institute of California.

Poterba, J. M., \& Rueben, K.S. (1999b). State fiscal institutions and the U.S. municipal bond Market. In J. Poterba \& J. von Hagen (Eds.), Fiscal Institutions and Fiscal Performance (pp. 181-208). Chicago: University of Chicago Press.

Prud'homme, R.(1995). On the dangers of decentralization. World Bank Research Observer, 10, 210226.

Reinhart, C. M., \& Rogoff, K.S. (2004). The modern history of exchange rate arrangements: a reinterpretation. Quarterly Journal of Economics, 119, 1- 48.

Roubini, N., \& Sachs, J.D. (1989). Political and economic determinants of budget deficits in the industrial democracies. European Economic Review, 33, 903-938.

Schaechter, A., Kinda, T., Budina, N., \& Weber, A. (2012). Fiscal rules in response to the crisis-toward the "next-generation" rules: a new dataset. IMF Working Paper No. 12/187.

Thornton, J., \& Vasilakis, C. (2016). Does inflation targeting reduce sovereign risk? Further evidence. Finance Research Letters, 18, 237-241.

Webb, S.B. (2004). Fiscal responsibility laws for sub-national discipline: the Latin American experience. World Bank Policy Research Working Paper No. 3309. 


\section{TABLE 1}

Developing countries with and without numerical fiscal rules

Panel A. Treatment group: countries with rules on the fiscal balance and/or public debt and year from which rule was in place (in parenthesis)

Armenia (2008), Benin 2000), Burkina Faso (2000), Burundi (2013), Cameroon (2002), Central African Republic (2002), Chad (2002), Republic of the Congo (2002), Cote d'Ivoire (1999), India (2004), Indonesia (1985), Kenya (2013), Liberia (2009), Mali (1999), Mongolia (2013), Niger (1999), Nigeria (2007), Pakistan (2005), Paraguay (2015), Senegal (1999), Sri Lanka (2003), Tanzania (2013), Togo (1999), Uganda (2013)

Panel B. Control group: countries with no fiscal rules

Bangladesh, Bolivia, Cambodia, Democratic Republic of the Congo, Djibouti, Egypt, El Salvador, Ethiopia, Gambia, Georgia, Ghana, Guatemala, Guinea, Guinea-Bissau, Guyana, Haiti, Honduras, Lesotho, Madagascar, Malawi, Mauritania, Moldova, Morocco, Mozambique, Nepal, Nicaragua, Papua New Guinea, Philippines, Sierra Leone, Sudan, Swaziland, Syrian Arab Republic, São Tomé and Principe, Ukraine, Vietnam, Yemen, Zimbabwe Note. Developing countries comprise low-income and lower-middle-income countries in the World Bank's country classification system.

Source: Schaechter et al. (2012). The sample is an unbalanced panel for the period 1985-2017. 
TABLE 2

Descriptive statistics

\begin{tabular}{|c|c|c|c|c|c|}
\hline & Mean & Median & Maximum & Minimum & $\begin{array}{l}\text { Standard } \\
\text { deviation }\end{array}$ \\
\hline \multicolumn{6}{|l|}{ A. Treatment group } \\
\hline $\begin{array}{l}\text { Domestic borrowing } \\
\text { spread }\end{array}$ & 6.525 & 6.698 & 18.668 & -27.150 & 4.833 \\
\hline Treasury bill yield & 11.499 & 10.080 & 55.704 & 2.959 & 6.779 \\
\hline Public debt to GDP & 65.545 & 56.745 & 513.872 & 7.276 & 52.260 \\
\hline Inflation (\%) & 13.601 & 5.303 & 3373.470 & -14.936 & 123.634 \\
\hline GDP growth (\%) & 3.814 & 4.500 & 33.736 & -51.031 & 6.157 \\
\hline $\begin{array}{l}\text { Per capita GDP (2012 } \\
\text { US\$) }\end{array}$ & 1171.309 & 842.810 & 4219.368 & 115.791 & 916.695 \\
\hline External trade to GDP & 62.738 & 55.402 & 311.355 & 12.352 & 32.114 \\
\hline External public debt & 49.762 & 39.645 & 286.403 & 1.271 & 40.210 \\
\hline Exchange rate regime & 1.862 & 1.000 & 6.000 & 1.000 & 1.137 \\
\hline \multicolumn{6}{|l|}{ B. Control group } \\
\hline $\begin{array}{l}\text { Domestic borrowing } \\
\text { spread }\end{array}$ & 7.175 & 5.292 & 52.310 & -20.507 & 8.201 \\
\hline Treasury bill yield & 11.846 & 9.996 & 78.632 & 0.029 & 8.201 \\
\hline Public debt to GDP & 89.010 & 59.735 & 2092.900 & 10.230 & 107.837 \\
\hline Inflation (\%) & 110.355 & 8.734 & 24411.031 & -11.449 & 1175.007 \\
\hline GDP growth (\%) & 3.699 & 4.299 & 26.845 & -44.900 & 5.238 \\
\hline $\begin{array}{l}\text { Per capita GDP ( } 2012 \\
\text { US\$) }\end{array}$ & 1437.628 & 1138.247 & 6506.500 & 131.646 & 1114.256 \\
\hline External trade to GDP & 74.469 & 66.651 & 280.361 & 11.087 & 36.845 \\
\hline External public debt & 65.975 & 43.389 & 830.269 & 2.149 & 75.083 \\
\hline Exchange rate regime & 2.452 & 2.000 & 6.000 & 1.000 & 1.317 \\
\hline
\end{tabular}

Note. See Appendix for variable definitions and sources. 
TABLE 3

Probit estimates of propensity scores for numerical fiscal rule adoption

\begin{tabular}{|c|c|c|c|c|c|}
\hline \multirow{2}{*}{ Lagged public debt to GDP } & 1 & 2 & 3 & 4 & \\
\hline & $\begin{array}{l}-0.0034 * * * \\
(0.0010)\end{array}$ & $\begin{array}{l}-0.0037 * * * \\
(0.0011)\end{array}$ & $\begin{array}{l}-0.0037 * * * \\
(0.0010)\end{array}$ & & $\begin{array}{l}-0.00 \\
(0.00\end{array}$ \\
\hline Inflation & $\begin{array}{l}-0.0317^{* * *} \\
(0.0094)\end{array}$ & $\begin{array}{l}-0.0322 * * * \\
(0.0097)\end{array}$ & $\begin{array}{l}-0.0288 * * * \\
(0.0079)\end{array}$ & $\begin{array}{l}-0.0330 * * * \\
(0.0099)\end{array}$ & $\begin{array}{l}-0.31 \\
(0.00\end{array}$ \\
\hline GDP growth & $\begin{array}{c}0.0117 \\
(0.0123)\end{array}$ & $\begin{array}{c}0.0113 \\
(0.0123)\end{array}$ & $\begin{array}{c}0.0162 \\
(0.0119)\end{array}$ & $\begin{array}{c}0.0122 \\
(0.0122)\end{array}$ & $\begin{array}{r}0.01 \\
(0.01\end{array}$ \\
\hline Log GDP per capita & $\begin{array}{l}0.1099^{*} \\
(0.0592)\end{array}$ & $\begin{array}{l}0.1345^{* *} \\
(0.0621)\end{array}$ & $\begin{array}{l}0.1326^{* *} \\
(0.0624)\end{array}$ & $\begin{array}{c}0.0269 \\
(0.0609)\end{array}$ & $\begin{array}{r}0.11 \\
(0.05\end{array}$ \\
\hline Trade to GDP & $\begin{array}{l}-0.0091 * * * \\
(0.0648)\end{array}$ & $\begin{array}{l}-0.0091 * * * \\
(0.0016)\end{array}$ & $\begin{array}{l}-0.0079 * * * \\
(0.0016)\end{array}$ & $\begin{array}{l}-0.0085^{* * *} \\
(0.0016)\end{array}$ & $\begin{array}{l}-0.00 \\
(0.00\end{array}$ \\
\hline Exchange rate regime & $\begin{array}{l}-0.5502 * * * \\
(0.0648)\end{array}$ & $\begin{array}{l}-0.5346^{* * *} \\
(0.0642)\end{array}$ & $\begin{array}{l}-0.4206^{* * *} \\
(0.0624)\end{array}$ & $\begin{array}{l}-0.5652 * * * \\
(0.0649)\end{array}$ & $\begin{array}{l}-0.54 \\
(0.06\end{array}$ \\
\hline Federation & $\begin{array}{l}0.2859 * * \\
(0.1424)\end{array}$ & $\begin{array}{l}0.3355^{* *} \\
(0.1488)\end{array}$ & $\begin{array}{r}0.2564 * \\
(0.1436)\end{array}$ & $\begin{array}{c}0.0200 \\
(0.1383)\end{array}$ & $\begin{array}{r}0.29 \\
(0.14\end{array}$ \\
\hline Debt relief & & $\begin{array}{r}0.1488^{*} \\
(0.0863)\end{array}$ & & & \\
\hline Financial repression & & & $\begin{array}{l}0.6887 * * * \\
(0.0980)\end{array}$ & & \\
\hline Lagged external debt to GDP & & & & $\begin{array}{l}-0.4306 * * * \\
(0.0593)\end{array}$ & \\
\hline Banking crisis & & & & & $\begin{array}{l}-0.94 \\
(0.41\end{array}$ \\
\hline Pseudo $\mathrm{R}^{2}$ & 0.175 & 0.177 & 0.208 & 0.212 & 0.181 \\
\hline Observations & 1547 & 1547 & 1547 & 1697 & 1547 \\
\hline
\end{tabular}

Note. Constant terms are included but not reported. Robust standard errors in parenthesis. ${ }^{* * *}, * *$, and * indicate $\mathrm{s} 1$ significance at the 1,5 and $10 \%$ levels, respectively 
TABLE 4

Matching estimate of the treatment effect of fiscal rules on relative borrowing costs of developing country governments: numerica

\begin{tabular}{|c|c|c|c|c|c|c|c|}
\hline & \multicolumn{7}{|c|}{ Matching methods } \\
\hline & \multirow{3}{*}{$\begin{array}{l}\text { Nearest } \\
\text { neighbor } \\
\text { matching }\end{array}$} & \multirow{3}{*}{$\begin{array}{l}\text { Three- } \\
\text { nearest } \\
\text { neighbor } \\
\text { matching }\end{array}$} & \multirow{2}{*}{\multicolumn{3}{|c|}{ Radius matching }} & \multirow{3}{*}{$\begin{array}{l}\text { Local linear } \\
\text { regression } \\
\text { matching }\end{array}$} & \multirow{3}{*}{$\mathrm{K}$} \\
\hline & & & & & & & \\
\hline & & & $\mathrm{r}=0.01$ & $\mathrm{r}=0.03$ & $\mathrm{r}=0.05$ & & \\
\hline \multirow[t]{2}{*}{ 1. Baseline } & $2.5705 * *$ & $1.8099 * *$ & $2.0970 * *$ & $1.8100 * *$ & $1.8787 * * *$ & $1.9111 * *$ & \\
\hline & $(0.9240)$ & $(0.8290)$ & $(0.7599)$ & $(0.6836)$ & $(0.6011)$ & $(0.6510)$ & $(1$ \\
\hline \multirow[t]{2}{*}{ 2. With debt reduction } & $2.8857 * *$ & $1.9837 * *$ & $2.4732 * * *$ & $2.0591 * *$ & $2.0321 * * *$ & $2.1017 * * *$ & \\
\hline & $(1.0825)$ & $(0.8243)$ & $(0.8319)$ & $(0.7252)$ & $(0.6612)$ & $(0.6070)$ & $(1$ \\
\hline \multirow[t]{2}{*}{ 3. With financial repression } & $1.4035^{*}$ & 0.9958 & $0.9783^{*}$ & $1.5233^{* *}$ & $1.9343 * * *$ & $1.4822 *$ & \\
\hline & $(0.7678)$ & (1.3507) & $(0.5567)$ & $(0.6937)$ & $(0.6526)$ & $(0.8299)$ & $(1$ \\
\hline \multirow[t]{2}{*}{ 4. With external debt } & $3.5223 * *$ & $2.2044 * *$ & $3.2365 * * *$ & $2.7473 * * *$ & $2.6830 * * *$ & $2.4848 * * *$ & \\
\hline & (1.2414) & $(1.0504)$ & $(0.8742)$ & $(0.8803)$ & $(0.8652)$ & $(0.7374)$ & $(1$ \\
\hline \multirow[t]{2}{*}{ 5. With banking crisis } & $1.9665 * *$ & $1.8835 * *$ & $2.1043 * *$ & $1.8909 * * *$ & $1.9059 * * *$ & $1.9604 * * *$ & \\
\hline & $(0.8915)$ & $(0.8471)$ & $(0.7608)$ & $(0.6296)$ & $(0.6105)$ & $(0.6305)$ & $(1$ \\
\hline
\end{tabular}

Note. A 0.06 fixed bandwidth and an Epanechnikov kernel are used for kernel and local linear regression matching. Bootstrapped s are reported in parenthesis. ${ }^{* * *}$ indicate statistical significance at the levels of $1 \%$. ${ }^{* *}$ indicate statistical significance at the levels c indicate statistical significance at the levels of $10 \%$. 
TABLE 5

Matching estimate of the treatment effect of fiscal rules on domestic treasury bill yields of developing country governments: numerical rule adoption

\begin{tabular}{|c|c|c|c|c|c|c|c|}
\hline & \multicolumn{7}{|c|}{ Matching methods } \\
\hline & \multirow[t]{2}{*}{$\begin{array}{l}\text { Nearest } \\
\text { neighbor } \\
\text { matching }\end{array}$} & \multirow{2}{*}{$\begin{array}{l}\text { Three- } \\
\text { nearest } \\
\text { neighbor } \\
\text { matching }\end{array}$} & \multicolumn{3}{|c|}{ Radius matching } & \multirow[t]{2}{*}{$\begin{array}{l}\text { Local linear } \\
\text { regression } \\
\text { matching }\end{array}$} & \multirow{2}{*}{$\begin{array}{l}\text { Kernal } \\
\text { matching }\end{array}$} \\
\hline & & & $\mathrm{r}=01$ & $\mathrm{r}=0.03$ & $\mathrm{r}=0.05$ & & \\
\hline \multicolumn{8}{|l|}{$\begin{array}{l}\text { A. Nominal } \\
\text { treasury bill } \\
\text { yield }\end{array}$} \\
\hline Baseline & $\begin{array}{l}-1.2122 \\
(0.9533)\end{array}$ & $\begin{array}{l}-1.7479 * * \\
(0.7783)\end{array}$ & $\begin{array}{l}-1.1991^{*} \\
(0.6699)\end{array}$ & $\begin{array}{l}-1.1574^{*} \\
(0.6291)\end{array}$ & $\begin{array}{l}-1.0687^{*} \\
(0.6044)\end{array}$ & $\begin{array}{l}-1.1422 * \\
(0.6355)\end{array}$ & $\begin{array}{l}-1.0901 \\
(0.6492)\end{array}$ \\
\hline $\begin{array}{l}\text { With debt } \\
\text { reduction }\end{array}$ & $\begin{array}{l}-1.7785^{* *} \\
(0.7979)\end{array}$ & $\begin{array}{l}-1.8665^{*} \\
(1.0947)\end{array}$ & $\begin{array}{l}-1.7918^{* *} \\
(0.7536)\end{array}$ & $\begin{array}{l}-1.9419^{* *} \\
(0.6643)\end{array}$ & $\begin{array}{l}-1.9604 * * * \\
(0.6370)\end{array}$ & $\begin{array}{l}-1.9830 * * * \\
(0.6281)\end{array}$ & $\begin{array}{l}-1.9680 * * * \\
(0.6048)\end{array}$ \\
\hline $\begin{array}{l}\text { With external } \\
\text { debt }\end{array}$ & $\begin{array}{l}-2.4976^{* *} \\
(1.0639)\end{array}$ & $\begin{array}{l}-2.3456 * * \\
(0.8796)\end{array}$ & $\begin{array}{l}-1.2306^{*} \\
(0.6848)\end{array}$ & $\begin{array}{l}-1.4794 * * \\
(0.5794)\end{array}$ & $\begin{array}{l}-1.6711 * * \\
(0.5967)\end{array}$ & $\begin{array}{l}-1.8436 * * * \\
(0.6075)\end{array}$ & $\begin{array}{l}-1.6934 * * \\
(0.6221)\end{array}$ \\
\hline $\begin{array}{l}\text { With banking } \\
\text { crisis }\end{array}$ & $\begin{array}{l}-1.3337^{*} \\
(0.7141)\end{array}$ & $\begin{array}{l}-1.4577^{*} \\
(0.8043)\end{array}$ & $\begin{array}{l}-1.1865^{*} \\
(0.6574)\end{array}$ & $\begin{array}{l}-1.0330^{*} \\
(0.5572)\end{array}$ & $\begin{array}{l}-0.9397 * \\
(0.4640)\end{array}$ & $\begin{array}{l}-1.0257^{*} \\
(0.5586)\end{array}$ & $\begin{array}{l}-0.9662 * \\
(0.5522)\end{array}$ \\
\hline \multicolumn{8}{|l|}{$\begin{array}{l}\text { B. Real treasury } \\
\text { bill yield }\end{array}$} \\
\hline Baseline & $\begin{array}{l}-1.9078^{*} \\
(1.0626)\end{array}$ & $\begin{array}{l}-1.8378^{*} \\
(1.0244)\end{array}$ & $\begin{array}{l}-0.7827^{*} \\
(0.4745)\end{array}$ & $\begin{array}{l}-0.6926^{*} \\
(0.3811)\end{array}$ & $\begin{array}{l}-0.7514^{*} \\
(0.3988)\end{array}$ & $\begin{array}{l}-0.7577 * * \\
(0.3560)\end{array}$ & $\begin{array}{l}-0.7173 \\
(0.9480)\end{array}$ \\
\hline With debt & $-1.6780 * *$ & $-1.4000 * *$ & $-1.1166^{*}$ & -1.5546 & -1.5727 & $-1.6056^{* *}$ & $-1.5777^{*}$ \\
\hline reduction & $(0.7781)$ & $(0.4823)$ & $(0.6608)$ & $(0.9779)$ & (1.0009) & $(0.8322)$ & $(0.8764)$ \\
\hline With external & $-2.1911^{*}$ & $-1.5486^{*}$ & $-1.2443^{*}$ & $-1.8707^{*}$ & $-1.0818^{*}$ & $-1.4066^{*}$ & $-1.1174^{*}$ \\
\hline debt & $(1.2321)$ & $(0.9362)$ & $(0.7304)$ & $(1.0471)$ & $(0.5748)$ & $(0.8491)$ & $(1.0221)$ \\
\hline $\begin{array}{l}\text { With banking } \\
\text { crisis }\end{array}$ & $\begin{array}{l}-2.2359^{*} \\
(1.2497)\end{array}$ & $\begin{array}{l}-1.9331^{*} \\
(1.15280\end{array}$ & $\begin{array}{l}-1.8263^{*} \\
(1.0693)\end{array}$ & $\begin{array}{l}-1.7773 * \\
(1.0634)\end{array}$ & $\begin{array}{l}-1.6949^{*} \\
(1.0202)\end{array}$ & $\begin{array}{l}-1.6604^{*} \\
(1.0046)\end{array}$ & $\begin{array}{l}-1.7926^{*} \\
(1.0564)\end{array}$ \\
\hline
\end{tabular}

Note. A 0.06 fixed bandwidth and an Epanechnikov kernel are used for kernel and local linear regression matching.

Bootstrapped standard errors are reported in parenthesis. ${ }^{* * *}$ indicate statistical significance at the levels of $1 \% .{ }^{* *}$ indicate statistical significance at the levels of $5 \% .{ }^{*}$ indicate statistical significance at the levels of $10 \%$. 
TABLE 6

Probit estimates of propensity scores for strong numerical fiscal rule adoption

\begin{tabular}{|c|c|c|c|c|c|}
\hline & 1 & 2 & 3 & 4 & 5 \\
\hline \multirow[t]{2}{*}{ Lagged public debt } & $-0.0067 * * *$ & $-0.0073 * * *$ & $-0.0068 * * *$ & & $-0.0067 * * *$ \\
\hline & $(0.0014)$ & $(0.0015)$ & $(0.0012)$ & & $(0.0014)$ \\
\hline \multirow[t]{2}{*}{ Inflation } & $-0.0499 * * *$ & $-0.0525 * * *$ & $-0.448 * * *$ & $-0.0551 * * *$ & $-0.0516 * * *$ \\
\hline & $(0.0074)$ & $(0.0078)$ & $(0.0071)$ & $(0.0071)$ & $(0.0078)$ \\
\hline \multirow[t]{2}{*}{ GDP growth } & 0.0123 & 0.0119 & 0.0136 & 0.0616 & 0.0099 \\
\hline & $(0.0114)$ & $(0.0114)$ & $(0.1147)$ & $(0.0120)$ & $(0.0114)$ \\
\hline \multirow[t]{2}{*}{ GDP per capita } & $-0.3341 * * *$ & $-3.007 * * *$ & $-0.0307 * * *$ & $-0.3856 * * *$ & $-0.3353 * * *$ \\
\hline & $(0.0734)$ & $(0.0760)$ & $(0.0743)$ & $(0.0730)$ & $(0.0741)$ \\
\hline \multirow[t]{2}{*}{ Trade to GDP } & -0.0002 & 0.0002 & 0.0005 & -0.0001 & -0.0004 \\
\hline & $(0.0015)$ & $(0.0015)$ & $(0.0016)$ & $(0.0015)$ & $(0.0015)$ \\
\hline \multirow[t]{2}{*}{ Exchange rate regime } & $-0.8662 * * *$ & $-0.8550 * * *$ & $-0.7425 * * *$ & $-0.9023 * * *$ & $-0.8781 * * *$ \\
\hline & $(0.0931)$ & $(0.0935)$ & $(0.0845)$ & $(0.0937)$ & $(0.0937)$ \\
\hline \multirow[t]{2}{*}{ Federation } & 0.2909 & $0.2743 * *$ & $0.2464 *$ & $0.3355 * *$ & $0.3676 * *$ \\
\hline & $(0.1424)$ & $(0.1064)$ & $(0.1336)$ & $(0.1488)$ & $(0.1234)$ \\
\hline \multirow[t]{2}{*}{ Debt relief } & & $0.2743 * *$ & & & \\
\hline & & $(0.1064)$ & & & \\
\hline \multirow[t]{2}{*}{ Financial repression } & & & $0.4286^{* * *}$ & & \\
\hline & & & $(0.1228)$ & & \\
\hline \multirow[t]{2}{*}{ Lagged external debt } & & & & $-0.5293 * * *$ & \\
\hline & & & & $(0.0705)$ & \\
\hline \multirow[t]{2}{*}{ Banking crisis } & & & & & $-0.8469 * *$ \\
\hline & & & & & $(0.3153)$ \\
\hline Pseudo $\mathrm{R}^{2}$ & 0.289 & 0.295 & 0.298 & 0.312 & 0.293 \\
\hline Observations & 1401 & 1400 & 1401 & 1530 & 1369 \\
\hline
\end{tabular}

Note. Constant terms are included but not reported. Robust standard errors in parenthesis. ***, **, and * indicate statistical significance at the 1,5 and $10 \%$ levels, respectively 
TABLE 7

Matching estimate of the treatment effect of fiscal rules on relative borrowing costs of developing country governments: strong nu adoption

\begin{tabular}{|c|c|c|c|c|c|c|c|}
\hline & \multicolumn{7}{|c|}{ Matching methods } \\
\hline & \multirow[t]{2}{*}{$\begin{array}{l}\text { Nearest } \\
\text { neighbor } \\
\text { matching }\end{array}$} & \multirow[t]{2}{*}{$\begin{array}{l}\text { Three- } \\
\text { nearest } \\
\text { neighbor } \\
\text { matching }\end{array}$} & \multicolumn{3}{|c|}{ Radius matching } & \multirow[t]{2}{*}{$\begin{array}{l}\text { Local linear } \\
\text { regression } \\
\text { matching }\end{array}$} & \multirow[t]{2}{*}{ Kerr } \\
\hline & & & $\mathrm{r}=0.01$ & $\mathrm{r}=0.03$ & $\mathrm{r}=0.05$ & & \\
\hline 1. Baseline & $\begin{array}{l}6.5550 * * \\
(3.0880)\end{array}$ & $\begin{array}{l}5.3272 * * \\
(2.3825)\end{array}$ & $\begin{array}{l}5.5122 * * * \\
(1.3933)\end{array}$ & $\begin{array}{l}3.9736 * * * \\
(0.9669)\end{array}$ & $\begin{array}{l}3.6049 * * * \\
(0.9332)\end{array}$ & $\begin{array}{l}3.6620 * * * \\
(0.8576)\end{array}$ & $\begin{array}{l}3.77 \\
(0.92\end{array}$ \\
\hline 2. With debt reduction & $\begin{array}{c}0.8082 \\
(2.7127)\end{array}$ & $\begin{array}{c}4.1129^{*} \\
(2.4356)\end{array}$ & $\begin{array}{l}4.6253 * * * \\
(1.2588)\end{array}$ & $\begin{array}{l}3.9220 * * * \\
(0.9493)\end{array}$ & $\begin{array}{l}3.6372 * * * \\
(0.8909)\end{array}$ & $\begin{array}{l}3.5976^{* * *} \\
(0.8189)\end{array}$ & $\begin{array}{c}3.72 \\
(0.9:\end{array}$ \\
\hline 3. With financial repression & $\begin{array}{l}6.5092 * * * \\
(2.6819)\end{array}$ & $\begin{array}{l}6.6701 * * \\
(1.9887)\end{array}$ & $\begin{array}{l}5.0371 * * * \\
(1.0334)\end{array}$ & $\begin{array}{l}3.6536^{* * * *} \\
(0.8941)\end{array}$ & $\begin{array}{l}3.6393 * * * \\
(0.8558)\end{array}$ & $\begin{array}{l}3.5928 * * * \\
(0.8796)\end{array}$ & $\begin{array}{l}3.69 \\
(0.86\end{array}$ \\
\hline 4. With external debt & $\begin{array}{c}3.2019^{*} \\
(1.8645)\end{array}$ & $\begin{array}{l}4.5711^{* *} \\
(1.7535)\end{array}$ & $\begin{array}{l}4.7349 * * * \\
(1.3536)\end{array}$ & $\begin{array}{l}3.8702 * * * \\
(0.9230)\end{array}$ & $\begin{array}{l}3.2461 * * * \\
(0.9013)\end{array}$ & $\begin{array}{l}3.4343 * * * \\
(0.8549)\end{array}$ & $\begin{array}{r}3.43 \\
(0.85\end{array}$ \\
\hline 5. With banking crisis & $\begin{array}{l}12.1673^{* * *} \\
(4.0515)\end{array}$ & $\begin{array}{l}6.8692^{* *} \\
(2.7436) \\
\end{array}$ & $\begin{array}{l}5.4394 * * * \\
(1.3603) \\
\end{array}$ & $\begin{array}{l}4.0284^{* * *} \\
(1.0045)\end{array}$ & $\begin{array}{l}3.6545^{* * *} \\
(0.9771)\end{array}$ & $\begin{array}{l}3.7254 * * * \\
(0.9172)\end{array}$ & $\begin{array}{r}3.83 \\
(0.9< \\
\end{array}$ \\
\hline
\end{tabular}

Note. A 0.06 fixed bandwidth and an Epanechnikov kernel are used for kernel and local linear regression matching. Bootstrapped s errors are reported in parenthesis. ${ }^{* * *}$ indicate statistical significance at the levels of $1 \%$. $* *$ indicate statistical significance at the 1 * indicate statistical significance at the levels of $10 \%$. 


\begin{tabular}{|c|c|c|}
\hline \multicolumn{3}{|l|}{ APPENDIX } \\
\hline Variable & Definition & Sources \\
\hline Fiscal rule dummy & $\begin{array}{l}\text { A } 0-1 \text { dummy that takes the value of } 1 \text { in the year a } \\
\text { fiscal rule is in place for the fiscal deficit and/or the } \\
\text { stock of public debt and } 0 \text { otherwise }\end{array}$ & $\begin{array}{l}\text { Schaechter et al. (2012) and the } \\
\text { IMF's Fiscal Rules Dataset, } 2016\end{array}$ \\
\hline $\begin{array}{l}\text { Domestic borrowing } \\
\text { spread }\end{array}$ & $\begin{array}{l}\text { Risk premium on lending is the interest rate charged by } \\
\text { banks on loans to private sector customers minus the } \\
\text { "risk free" treasury bill interest rate at which short-term } \\
\text { government securities are issued or traded in the market. } \\
\text { In some countries this spread may be negative, indicating } \\
\text { that the market considers its best corporate clients to be } \\
\text { lower risk than the government. The terms and conditions } \\
\text { attached to lending rates differ by country, however, } \\
\text { limiting their comparability. }\end{array}$ & $\begin{array}{l}\text { World Bank, World } \\
\text { Development Indicators }\end{array}$ \\
\hline Treasury bill rate & $\begin{array}{l}\text { Treasury bill interest rate at which short-term government } \\
\text { securities are issued or traded in the local market. }\end{array}$ & $\begin{array}{l}\text { Datastream and IMF, } \\
\text { International Financial Statistics } \\
\text { database }\end{array}$ \\
\hline Public debt & Ratio of public debt outstanding to GDP & $\begin{array}{l}\text { Abbas et al. }(2010) \text { and IMF, } \\
\text { World Economic Outlook } \\
\text { database }\end{array}$ \\
\hline Inflation $(\%)$ & Annual percent change in consumer price index & $\begin{array}{l}\text { World Bank, World } \\
\text { Development Indicators }\end{array}$ \\
\hline GDP growth $(\%)$ & Annual percent change in real GDP & $\begin{array}{l}\text { World Bank, World } \\
\text { Development Indicators }\end{array}$ \\
\hline Log of per capita GDP & Log of real GDP per capita constant 2010 US\$ & $\begin{array}{l}\text { World Bank, World } \\
\text { Development Indicators }\end{array}$ \\
\hline External trade & Ratio of exports plus imports to GDP & $\begin{array}{l}\text { World Bank, World } \\
\text { Development Indicators }\end{array}$ \\
\hline Exchange rate regime & $\begin{array}{l}\text { Reinhart and Rogoff's (2004) coarse grid categorization, } \\
\text { which ranges from } 1 \text { [least flexible] to } 5 \text { [most flexible]); }\end{array}$ & Reinhart and Rogoff (2004) \\
\hline Federation dummy & $\begin{array}{l}\text { A } 0-1 \text { dummy that takes the value of } 1 \text { if the country } \\
\text { is a Federation and } 0 \text { otherwise }\end{array}$ & CIA Factbook \\
\hline Debt reduction dummy & $\begin{array}{l}\text { A } 0-1 \text { dummy that takes the value of } 1 \text { in the year that } \\
\text { a country receives external debt relief and } 0 \\
\text { otherwise }\end{array}$ & $\begin{array}{l}\text { World Bank, World } \\
\text { Development Indicators }\end{array}$ \\
\hline Financial repression & $\begin{array}{l}\text { Treasury bill interest rate at which short-term government } \\
\text { securities are issued or traded in the local market less } \\
\text { annual rate of inflation }\end{array}$ & $\begin{array}{l}\text { Datastream, IMF, International } \\
\text { Financial Statistics database; and } \\
\text { World Bank, World } \\
\text { Development Indicators }\end{array}$ \\
\hline External debt & Ratio of external public debt to GDP & $\begin{array}{l}\text { World Bank, World } \\
\text { Development Indicators }\end{array}$ \\
\hline Banking crisis dummy & $\begin{array}{l}\text { A } 0-1 \text { dummy that takes the value of } 1 \text { in a year that a } \\
\text { country experienced a systemic banking crisis and } 0 \\
\text { otherwise }\end{array}$ & Laeven and Valencia (2012). \\
\hline $\begin{array}{l}\text { Fiscal rule strength } \\
\text { index }\end{array}$ & $\begin{array}{l}\text { The index is an aggregation of the number of supportive } \\
\text { arrangements in place listed in Schaechter et al. }(2012) \text { as } \\
\text { desirable to strengthen fiscal rules. Schaechter et al. } \\
(2012) \text {. The variable is a } 0-1 \text { dummy that takes the value } \\
\text { of } 1 \text { if the value of the index is above the median value for } \\
\text { all countries }\end{array}$ & $\begin{array}{l}\text { Schaechter et al. (2012) and author } \\
\text { calculations }\end{array}$ \\
\hline
\end{tabular}


